\title{
Quality characteristics and antioxidant activities of macarons supplemented with white sesame
}

\author{
Su Jin Kim, Da Hee Kim, Seung Yeon Baek, Young Mi Park, Mee Ree Kim* \\ Department of Food and Nutrition, Chungnam National University, Daejeon 34134, Korea
}

\section{흰 참깨를 첨가한 마카롱의 품질 특성 및 항산화능

$$
\begin{gathered}
\text { 김수진 · 김다희 · 백승연 · 박영미 · 김미리* } \\
\text { 충남대학교 식품영양학과 }
\end{gathered}
$$

\begin{abstract}
This study evaluated the physicochemical properties and antioxidant activitiy of macarons containing white sesame powder $(0 \%, 15 \%, 30 \%$, and $45 \%)$. The moisture content and weight of macarons containing white sesame were higher than those of the macarons not containing any (control), and these increased with increasing white sesame content. However, the volume of macarons containing white sesame was lower than that of the control. The soluble solid content ( $\left.{ }^{\circ} \mathrm{Brix}\right)$ and reducing sugar content (\%) of the control were the lowest among all the experiment groups. The $\mathrm{pH}$ of the macarons decreased as the amount of white sesame increased. As the amount of white sesame increased, in the Hunter color system, $L^{*}$ (lightness) values of the white sesame containing macarons decreased, whereas $a^{*}$ (redness) and $b^{*}$ (yellowness) values increased. Analysis of textural properties by TPA showed that macaron hardness decreased with increasing white sesame content. Flavonoid and total phenolic contents increased with the addition of white sesame. Antioxidant activities such as DPPH (2,2-diphenyl-1-picrylhydrazyl) radical scavenging and superoxide dismutase-like activities, of the macarons containing white sesame increased compared with the control. Analysis of the sensory properties revealed that the score of overall acceptability of macarons containing $15 \%$ and $30 \%$ white sesame was the highest among all the groups. There, our findings suggested that it was desirable to add white sesame to macarons for enhanced quality and sensory characteristics.
\end{abstract}

Key words : white sesame, macaron, quality characteristics, antioxidant activities

서 론

참깨(Sesamum indicum)는 참깨과 참깨속의 일년생 초본 식물로 우리나라를 비롯해 중국, 일본, 인도 등과 세계 전역 에서 재배된다. 참깨는 들깨, 땅콩, 유채와 함께 주요 유지원 료 중 하나로 고소하고 특유한 향미를 가지고 있어 우리나라 와 중국 등지에서 오래전부터 아주 중요한 조미용 양념 및 식용유지로서 활용되어 왔다(Namiki, 1995). 참깨는 흰색, 갈
색, 검정색 등 종피의 색이 다양하며, 이에 따라 탄수화물, 단 백질, 지방, 리그난 등 구성성분도 차이가 있는데, 그 중 흰깨 는 검은깨보다 지용성 리그난 성분인 세사민과 세사몰린 함 량이 높은 것으로 보고되었다(Kanu, 2011).

참깨는 지질 함량이 약 $50 \%$ 에 이르는 유료작물로 불포화 지방산이 풍부하며, 주로 올레산과 리놀레산을 함유하고 있 으며, 그 종실 부위나 종실로부터 얻은 기름이 널리 식용되고 있다(Namiki, 2007). 참깨 종실에는 단백질(약 $20 \%$ )을 함유

*Corresponding author. E-mail : mrkim@cnu.ac.kr, Phone : +82-42-821-6837, Fax : +82-42-821-8671

Received 07 September 2020; Revised 26 October 2020; Accepted 25 November 2020.

Copyright (c) The Korean Society of Food Preservation.

This is an Open Access article distributed under the terms of the Creative Commons Attribution Non-Commercial License (http://creativecommons.org/licenses/by-nc/4.0) which permits unrestricted non-commercial use, distribution, and reproduction in any medium, provided the original work is properly cited. 
하고 있으며, 탄수화물(약 $20 \%)$ 뿐 아니라, 비타민 $\mathrm{B}_{1}$, 비타민 $\mathrm{B}_{2}, \gamma$-tocopherol, 인, 아연, 철 등이 함유되어 있는데, 특히 칼 슘 함량이 높아 식재료로서의 영양학적 가치가 크다(Orruno 와 Morgan, 2007).

참깨 종자에는 세사민, 세사몰린과 같이 그 자체가 항산화 활성을 나타내거나, 가공 중에 항산화 성분으로 전환되는 전구 체로서의 성분인 세사몰, 세사미놀 등의 리그난류 화합물이 다 량 함유되어 있다(Hosseinian 등, 2006). 리그난 화합물 성분에 관한 생리활성 기능 연구 결과에 따르면 식품 및 생체 내 지질 산화방지(Kang 등, 1999)와 심혈관계 보호작용(Dupasquier 등, 2006), 신경세포보호효과(Hou 등, 2003) 등의 다양한 체내 생 리활성을 나타내는 것으로 나타났다. 또한 다른 유지류에 비해 높은 산화 안정성을 나타내고, 항노화, 항암, 고혈압 강하 등의 기능(Fukuda 등, 1986; Ide 등, 2001)을 한다고 보고되어 다양 한 체내 생리활성을 지닌 식품 소재로 부각되었고, 이와 함께 소비량도 증가하였다(Kang 등, 2000b). 또한, 리그난류 화합물 은 여성호르몬인 에스트로겐과 구조적으로 유사하여 체내에서 에스트로겐 수용체와 결합해 에스트로겐과 같은 효능을 내는 것으로 알려져 있다(Cornwell 등, 2004). 이러한 참깨 종자에 함유되어 있는 리그난 화합물들은 유리형 또는 당과 결합되어 있는 배당체의 형태로 존재하며, 배당체보다 유리형이 생리활 성이 더 강하다(Kumamoto 등, 1985; Miura 등, 2002).

마카롱은 밀가루가 들어가지 않는 쿠키류로 아몬드 분말, 달걀흰자, 설탕을 주재료로 하여 고소한 맛과 촉촉하고 부드 러운 식감이 특징이며, 서양에서는 고급 디저트로 알려져 있 다(Kim, 2017). 고급 제과류를 선호하는 소비자들이 증가함 에 따라 마카롱의 소비량은 꾸준히 증가하고 있으며, 우리나 라와 유럽뿐 아니라, 전세계에서도 고급 디저트로 주목받고 있다(Lee 등, 2015). 난백의 기포성을 이용하여 만드는 머랭
은 마카롱 반죽에 첨가되어 공기를 포집하여 마카롱을 부풀 게 하고, 결착능력을 가져 마카롱의 식감과 형태를 형성하도 록 한다. 머랭은 마카롱의 부피와 식감과 관련이 있는데, 머 랭의 안전성 정도에 따라 최종 제품의 부피나 질감 등에 영향 을 미치기 때문에 $70 \%$ 정도의 단단한 머랭을 올리는 것이 중요하다(Park 등, 2020a). 다양한 맛과 색상을 가지면서 기 능성물질을 부재료로 첨가한 마카롱의 개발이 활발하게 진행 되고 있으며, 현재 양배추분말(Kim, 2017), 들깨분말(Lee 등, 2015), 땅콩분말(Park 등, 2020b)을 첨가한 마카롱의 연구가 보고되었다.

참깨는 한국인의 식생활에서 매우 중요한 역할을 하고 있 으나, 지금까지 참깨는 주로 기름으로 이용해 왔고, 식품의 부 재료로서의 활용도는 미비한 편이다. 최근 삶의 질이 높아지 고 건강과 장수에 대한 관심이 많아지면서 건강식품 섭취가 증대되고 있음에 따라 영양적으로 우수하나 소비형태가 고정 되어 있는 참깨의 소비와 섭취를 증가시키기 위하여 이를 부 재료로 첨가한 마카롱 개발을 시도하였다. 흰 참깨를 부재료 로 활용한 마카롱의 품질 특성과 항산화성을 연구하고, 관능 평가를 통해 상품적 가치를 검토한 후, 마카롱의 적절한 참깨 첨가 비율과 제조조건을 제시하고자 한다.

\section{재료 및 방법}

\section{실험재료}

본 실험에 사용된 고운 흰 참깨분말(Kumho Food, Okcheon, Korea), 아몬드분말(G\&M Food System, Gyeongsan, Korea), 슈가파우더(Serom Food, Icheon, Korea), 달걀(Happiness Egg, Daejeon, Korea), 및 설탕(CJ CheilJedang, Incheon, Korea) 등은 마트에서 구입하여 사용하였다.

Table 1. Formulas for the macaron added with different ratio of white sesame powder

\begin{tabular}{|c|c|c|c|c|c|}
\hline \multirow{2}{*}{\multicolumn{2}{|c|}{ Ingredients (g) }} & \multicolumn{4}{|c|}{ White sesame powder (\%) } \\
\hline & & 0 & 15 & 30 & 45 \\
\hline \multirow{2}{*}{ Syrup } & Sugar & 60 & 60 & 60 & 60 \\
\hline & Water & 18.5 & 18.5 & 18.5 & 18.5 \\
\hline \multirow{2}{*}{ Meringue } & White egg & 24 & 24 & 24 & 24 \\
\hline & Sugar & 6 & 6 & 6 & 6 \\
\hline \multirow{5}{*}{ Paste } & Almond powder & 60 & 51 & 42 & 33 \\
\hline & White sesame powder & 0 & 9 & 18 & 27 \\
\hline & Sugar powder & 60 & 60 & 60 & 60 \\
\hline & White egg & 24 & 24 & 24 & 24 \\
\hline & Total & 252.5 & 252.5 & 252.5 & 252.5 \\
\hline
\end{tabular}




\section{마카롱 코크의 제조}

마카롱은 흰 참깨분말을 아몬드분말의 $15 \%, 30 \%, 45 \%$ 씩 각각 다른 비율로 첨가하여 이탈리안 머랭법으로 제조했으며, 재료 배합비는 Table 1 과 같다. 아몬드분말, 흰 참깨분말, 슈 가파우더를 섞은 후, 달걀흰자와 혼합하여 아몬드 페이스트를 만들었다. 달걀흰자를 믹서기(KMC510, De'Longhi-Kenwood Appliance Co. Ltd, Treviso, Italy)로 1단에서 30초간 섞은 후 설탕을 넣고 다시 3 단에서 2 분간 섞었다. $70 \%$ 정도 거품 에 도달하면 머랭에 물과 설탕을 넣고 $118^{\circ} \mathrm{C}$ 에서 만든 시럽 을 천천히 부어 이탈리안 머랭을 완성시켰다. 아몬드 페이스 트에 이탈리안 머랭을 3 회에 걸쳐 섞은 후 마카로나주를 50 회 반복을 통해 완성하였다. 짤주머니에 담아 일정한 무게로 짜서 실온에서 30 분간 표면을 건조시킨 다음 $150^{\circ} \mathrm{C}$ 로 예열한 오븐(Briox Facile, Gierre, Milano, Italy)에서 7분 구운 후 위 치를 180 도 돌려 8 분간 구웠다. 완성된 마카롱 코크는 실온 에서 1 시간 냉각하여 시료로 사용했다.

\section{항산화능 분석 시료의 제조}

분쇄한 마카롱 시료 $5 \mathrm{~g}$ 과 $100 \%$ 메탄올 $50 \mathrm{~mL}$ 를 4시간 동안 교반(Powersonic 420, Hwashin technology, Gwangju, Korea)하여 24시간 동안 추출하였다. 이를 $3,000 \mathrm{rpm}$ 으로 $4^{\circ} \mathrm{C}$ 에서 20 분간 원심분리하여 얻어진 상층액을 감압농축기 (EYELA SB-1000, Tokyo Rikakikai Co., Ltd., Tokyo, Japan)로 용매를 휘발하여 농축된 추출물만 얻었다. 시료 용 액은 각각의 추출물 $200 \mathrm{mg}$ 에 $1 \mathrm{~mL}$ 의 메탄올을 넣어 200 $\mathrm{mg} / \mathrm{mL}$ 농도로 제조하였다.

\section{수분함량 측정}

수분함량은 마카롱 내부를 약 $1.0 \mathrm{~g}$ 칭량하여 적외선 수분 측정기(FD-660, Kett Electric Laboratory, Tokyo, Japan)를 사용하여 측정했다.

\section{무게, 부피, 퍼짐성 측정}

일정한 마카롱 반죽의 무게로 마카롱 코크를 제조하여 실 온에서 완전히 식힌 후 무게는 전자저울(KS-514PK, Dretec Co., Ltd., Koshigaya, Japan)로 소수 둘째자리까지 측정했다. 부피는 종자치환법(Pyler, 1979)에 의해 비커에 시료를 담아 떨어진 좁쌀을 눈금 실린더로 3 회 반복 측정하여 평균값을 내었다. 퍼짐성은 마카롱 6 개의 직경과 높이를 각각 3 회 반복 측정하여 마카롱 1 개에 대한 직경과 높이를 구한 다음, 아래 와 같은 공식을 통해 퍼짐성을 계산하였다(AACC, 2000).

$$
\text { 퍼짐성(spread factor) }=\frac{\text { 쿠키 6개의 평균 너비 }(\mathrm{mm})}{\text { 쿠키 } 6 \text { 개의 평균 두께 }(\mathrm{mm})}
$$

\section{가용성 고형분, 환원당, $\mathrm{pH}$ 측정}

분쇄한 마카롱 시료 $5 \mathrm{~g}$ 과 증류수 $45 \mathrm{~mL}$ 를 혼합하여 sonication(Hwashin technology)에서 교반시킨 후 $\left(40^{\circ} \mathrm{C}, 30\right.$ $\mathrm{min})$, 원심분리하였다 $\left(3,000 \mathrm{rpm}, 4^{\circ} \mathrm{C}, 20 \mathrm{~min}\right)$. 상등액을 취 하여 당도계(SCM-1000, Hando, Daegu, Korea)로 가용성 고 형분 함량을 측정하였다. 환원당은 가용성 고형분 함량과 동 일한 시료를 dinitrosalicylic acid(DNS)에 의한 비색법에 의 해 $550 \mathrm{~nm}$ 에서 흡광도를 측정하였다. 표준곡선은 포도당 (Sigma Aldrich Co., St. Louis, MO, USA)을 농도별로 반응 시켜 사용하였다. $\mathrm{pH}$ 는 가용성 고형분 함량과 동일한 시료를 meter(420 Benchtop, Orion Research, Beverly, MA, USA)로 상등액을 측정하였다.

\section{색도 측정}

분쇄한 마카롱 시료 $10 \mathrm{~g}$ 을 취해 페트리디쉬 $(50 \times 12 \mathrm{~mm})$ 에 평평하게 담아 색차계(Spectrophotometer CM-600, Konica Minolta Sensing, Inc., Tokyo, Japan)로 측정했다. Standard color value는 $\mathrm{L}^{*}$ (lightness)값 99.37, a*(redness)값 -0.14, $\mathrm{b}^{*}$ (yellowness)값 -0.08 인 calibration plate를 표준으로 사용 하여 3 회 반복 측정하여 평균값으로 나타내었다.

\section{기계적 조직감 측정}

Texture analyser(TA/XT2, Stable Micro System Ltd., Surrey, England)를 사용하여 시료를 연속 2회 압축하였을 때, 얻어지는 힘-시간 곡선으로부터 경도, 탄력성, 응집성, 검 성, 씹힘성, 회복력을 측정하였다. Plunger(SMS P/5)를 사용 하여 측정조건은 pre-test speed, post-test speed 및 test speed 는 $2.0 \mathrm{~mm} / \mathrm{s}$ 로 통일하고, 압축 시 변형률 $20 \%$ 로 하였다.

\section{총페놀성 화합물 함량 측정}

$200 \mathrm{mg} / \mathrm{mL}$ 농도로 제조한 항산화능 시료 $50 \mu \mathrm{L}$ 에 증류수 $50 \mu \mathrm{L}$ 와 $0.2 \mathrm{~N}$ Folin-Ciocalteau reagent $500 \mu \mathrm{L}$ 를 넣고 5 분 간 반응시킨 후 $7.5 \% \mathrm{Na}_{2} \mathrm{CO}_{3} 400 \mu \mathrm{L}$ 를 넣고 암실에서 30 분 간 반응시키고 $760 \mathrm{~nm}$ 에서 흡광도를 측정하였다. 표준곡선 은 포화 tannic acid(Yakuri Pure Chemicals Co., Ltd., Kyoto, Japan)를 사용하여 마카롱 중량 $(\mathrm{g})$ 에 대한 tannic acid 함량인 tannic acid equivalent(TAE) $\mathrm{mg} / \mathrm{g}$ 으로 나타냈다.

\section{플라보노이드 함량 측정}

$200 \mathrm{mg} / \mathrm{mL}$ 농도로 제조한 항산화능 시료 $100 \mu \mathrm{L}$ 에 $90 \%$ diethylene glycol $0.9 \mathrm{~mL}, 1 \mathrm{~N} \mathrm{NaOH} 20 \mu \mathrm{L}$ 를 넣고 $37^{\circ} \mathrm{C}$ water bath에서 1시간 동안 반응시킨 뒤, $420 \mathrm{~nm}$ 에서 흡광도 를 측정하였다. 표준곡선은 naringin(Sigma Aldrich Co.)를 사용하여 마카롱 중량 $(\mathrm{g})$ 에 대한 naringin 함량인 naringin equivalent(NE) $\mathrm{mg} / \mathrm{g}$ 으로 나타냈다. 


\section{DPPH radical 소거능 측정}

$200 \mathrm{mg} / \mathrm{mL}$ 농도로 제조한 항산화능 시료 용액을 농도별 로 희석하여 희석용액 $50 \mu \mathrm{L}$ 에 $1.5 \times 10^{-4} \mathrm{mM} \mathrm{1,1-diphenyl-}$ 2-picrylhydrazyl(DPPH) 용액 $150 \mu \mathrm{L}$ 를 넣고 암실에서 30분 동안 반응시킨 후 $515 \mathrm{~nm}$ 에서 흡광도를 측정하였다. 아래 식 을 통해 DPPH radical 소거능(\%)을 계산하고, 농도별 radical 소거능에 대한 검량선에서 $\mathrm{DPPH}$ radical 소거능이 $50 \%$ 가 되는 농도인 $\mathrm{IC}_{50}$ 값을 구하였다.

DPPH radical scavenging activity $(\%)=$

$$
\frac{\mathrm{Abs}_{\mathrm{DPPH}}-\mathrm{Abs}_{\text {sample }}}{\mathrm{Abs}_{\mathrm{DPPH}}} \times 100
$$

\section{SOD 유사활성 측정}

$200 \mathrm{mg} / \mathrm{mL}$ 농도로 제조한 항산화능 시료 용액을 농도별 로 희석하여 희석용액 $40 \mu \mathrm{L}$ 에 Tris- $\mathrm{HCl}$ 의 완충용액 $(50 \mathrm{mM}$ Tris $+10 \mathrm{mM}$ EDTA, pH 8.5) $260 \mu \mathrm{L}$ 와 $7.2 \mathrm{mM}$ pyrogallol $20 \mu \mathrm{L}$ 를 넣고 $25^{\circ} \mathrm{C}$ 에서 10 분간 반응시켰다. $1 \mathrm{~N} \mathrm{HCl} 0.1$ $\mathrm{mL}$ 를 가하여 반응을 정지시키고, 산화된 pyrogallol의 양을 $420 \mathrm{~nm}$ 에서 흡광도로 측정하였다. 시료 첨가구와 무첨가구 사이의 흡광도 차이를 백분율로 나타내어 SOD 유사활성을 계산하였다.

$$
\text { SOD-like activity }(\%)=\left(1-\frac{\text { Abs }_{\text {sample }}}{\text { Abs }_{\text {blank }}}\right) \times 100
$$

\section{관능평가}

흰 참깨분말을 첨가한 마카롱의 관능적 특성을 알아보고, 적절한 첨가 비율과 제조조건을 제시하기 위해 강도 특성으 로 평가하였다(충남대학교 생명윤리위원회 생명윤리 면제심 의 윤리면제 승인번호: 202006-SB-075-01). 실험의 취지를 이해하고, 이에 동의한 충남대학교 식품영양학과 학생 중 검
사방법 및 관능적 품질 특성에 대한 교육과 예비검사를 실시 하여 8 명을 관능검사 요원으로 선발하였다. 모든 시료마다 무작위로 조합된 3자리 숫자의 난수표를 부여했으며, 시료는 동일 크기로 자른 후에 일회용 접시에 담아서 제공되었다. 7 점 척도법으로 평가(1점: 매우 약함, 7점: 매우 강함)했으며 평가항목은 시료의 외관[색(color), 매끄러운 정도(smooth)], 향[고소한 향(nutty flavor), 단 향(sweet flavor)], 맛[고소한 맛 (nutty taste), 단맛(sweetness)], 조직감[촉촉한 정도(moisture), 경도(hardness), 씹힘성(chewiness), 텁텁함(dull)], 전반적인 수용도(overall acceptability)로 나누어 실시하였다.

\section{통계처리}

모든 실험은 3 회 반복하여 측정하였고, 실험결과는 IBM SPSS statistics(24, IBM Corp., Armonk, NY, USA) software package 프로그램 중에서 기술통계를 실시하여 평균과 표준 오차를 구하여 나타냈다. 분산분석(ANOVA)을 수행하여 유 의적인 차이가 있는 경우, Duncan's multiple range test를 이 용하여 사후검정하였다 $(\mathrm{p}<0.05)$.

\section{결과 및 고찰}

\section{수분 함량}

흰 참깨를 첨가한 마카롱의 수분함량은 Table 2 와 같다. 대조군이 $10.22 \%$ 로 가장 낮았으며, 흰 참깨 $15 \%$ 첨가군은 $10.39 \%, 30 \%$ 첨가군은 $10.56 \%, 45 \%$ 첨가군은 $10.79 \%$ 로 나 타났다. 흰 참깨 첨가량에 따른 수분함량의 변화는 크지 않았 으나, 흰 참깨를 첨가할수록 수분함량이 증가하는 경향을 보 였다. 머랭 형성에서 유지류는 난백의 ovalbumin으로 형성된 막을 파괴하여 기포 안정성에 영향을 주는데 유분이 많은 경 우 머랭이 쉽게 사그라져 반죽이 질척해진다(Chae, 1997). 따 라서, 산지와 품종에 따라 차이가 있지만 참깨는 지질 함량이 약 50\%에 이르는 유료작물(Ryu 등, 2002)로 유화상태의 머 랭에서 수분이 유출되어 수분함량이 증가하는 것으로 사료된

Table 2. Moisture content, weight, volume and spread ratio of macaron added with white sesame powder

\begin{tabular}{ccccc}
\hline & \multicolumn{4}{c}{ White sesame powder (\%) } \\
\cline { 2 - 5 } & 0 & 15 & 30 & 45 \\
\hline Moisture content (\%) & $10.22 \pm 0.40^{1) \mathrm{b} 2)}$ & $10.39 \pm 0.15^{\mathrm{ab}}$ & $10.56 \pm 0.29^{\mathrm{ab}}$ & $10.79 \pm 0.21^{\mathrm{a}}$ \\
Weight $(\mathrm{g})$ & $9.73 \pm 0.06^{\mathrm{c}}$ & $10.00 \pm 0.10^{\mathrm{b}}$ & $10.13 \pm 0.15^{\mathrm{ab}}$ & $10.37 \pm 0.21^{\mathrm{a}}$ \\
Volume (mL) & $27.33 \pm 0.58^{\mathrm{a}}$ & $26.33 \pm 1.53^{\mathrm{a}}$ & $24.67 \pm 0.58^{\mathrm{b}}$ & $22.00 \pm 0.00^{\mathrm{c}}$ \\
Spread ratio & $4.26 \pm 0.10^{\mathrm{a}}$ & $3.84 \pm 0.05^{\mathrm{b}}$ & $3.86 \pm 0.53^{\mathrm{b}}$ & $4.06 \pm 0.27^{\mathrm{ab}}$ \\
\hline
\end{tabular}

\footnotetext{
${ }^{1)}$ All values are $\operatorname{mean} \pm \mathrm{SD}(\mathrm{n}=3)$.
}

${ }^{2}$ Different letters $\left({ }^{\mathrm{a}-\mathrm{c}}\right)$ in the same row are significantly different by Duncan's multiple range test at $\mathrm{p}<0.05$. 
다(Lee 등, 2017; Park 등, 2020b). 이러한 결과는 호박씨 가 루를 대체한 마카롱(Hong과 Yoon, 2020)과 수분함량이 증가 하는 유사한 경향이었으며, 흰 참깨를 첨가할수록 마카롱 내 부의 수분함량이 많아 보다 촉촉한 질감의 품질을 가질 것으 로 사료된다. 수분함량은 마카롱의 모양에도 영향을 주며 좋 은 품질의 마카롱의 경우 속반죽이 공기와 직접적으로 접촉 하지 않아 건조되지 않은 내부는 촉촉하고 부드러운 식감을 가진다고 하였다(Koo, 2018). 즉, 질감상 $45 \%$ 첨가군이 가장 좋았으며, 흰 참깨는 마카롱의 촉촉한 질감을 높이는데 기여 할 것으로 판단된다.

\section{무게, 부피, 퍼짐성}

흰 참깨를 첨가한 마카롱의 무게 및 부피는 Table 2 와 같 다. 무게는 대조군이 $9.73 \mathrm{~g}, 15 \%$ 첨가군이 $10.00 \mathrm{~g}, 30 \%$ 첨 가군이 $10.13 \mathrm{~g}, 45 \%$ 첨가군이 $10.37 \mathrm{~g}$ 으로 흰 참깨를 첨가 할수록 무게가 대조군에 비해 증가하는 것으로 나타났다. 부 피는 무게와 반대의 경향을 보여 대조군이 $27.33 \mathrm{~mL}, 15 \%$ 첨가군이 $26.33 \mathrm{~mL}, 30 \%$ 첨가군이 $24.67 \mathrm{~mL}, 45 \%$ 첨가군 이 $22.00 \mathrm{~mL}$ 로 흰 참깨 첨가량에 따라 감소하였다. 마카롱에 서 부피는 반죽 시 혼입되는 공기의 양뿐만 아니라, 구울 때 형성된 기포가 어느 정도 안정하게 유지되느냐에 따라 질 수 있는데, 본 연구에서는 흰 참깨의 첨가량을 증가시켰을 때, 흰 참깨의 높은 지질 함량으로 기포의 안정화 능력이 낮아져 부피가 감소하는 것으로 사료되었다(Hwang, 2020). 퍼짐성 은 대조군이 $4.26 \mathrm{~mm}$ 로 가장 수치가 컸고, $15,30,45 \%$ 흰 참깨 첨가군은 각각 $3.84,3.86,4.06 \mathrm{~mm}$ 로 대조군에 비해 낮은 수치를 보였다( $\mathrm{p}<0.05)$. 퍼짐성은 반죽의 점성에 의해 발생하는 현상으로 반죽의 유리 전이에 의한 연속적인 상태 가 되어 반죽이 유동상태가 중단될 때까지 일어난다(Miller 등. 1997). 퍼짐성은 반죽의 섬유소에 의한 보수력과 관련이 있는데, 아몬드(11.5\%)보다 흰 참깨(14.1\%)에 많은 식이섬유
로 인해 흰 참깨가 첨가됨에 따라 마카롱 반죽의 섬유소에 의 한 보수력이 증가하게 된다. 이에 따라 당의 용해에 필요한 수분을 섬유소가 가져감에 따라 당의 용해성과 보습성이 낮아 져 유동성에 필요한 일정한 점도를 상실해 퍼짐성이 낮아지는 결과는 보인 것으로 사료된다(Jung과 Lee, 2011).

\section{가용성 고형분, 환원당, $\mathrm{pH}$}

흰 참깨를 첨가한 마카롱의 가용성 고형분 함량, 환원당, $\mathrm{pH}$ 는 Table 3 과 같다. 가용성 고형분 함량은 대조군이 6.40 ${ }^{\circ} \mathrm{Brix}$, 흰 참깨 $15 \%$ 첨가군이 $6.50{ }^{\circ} \mathrm{Brix}, 30 \%$ 첨가군이 6.70 ${ }^{\circ} \mathrm{Brix}, 45 \%$ 첨가군이 $6.80{ }^{\circ} \mathrm{Brix}$ 으로 흰 참깨를 첨가할수록 미세하게 증가했으며 모든 실험군들 사이에서 유의적인 차이 를 보였다 $(\mathrm{p}<0.05)$. 설탕은 난백의 기포성과 안정성에 영향 을 미쳐 머랭의 점도를 높이고 거품이 형성되는 시간을 증가 시켜 난백의 기포 형성력을 저하시킨다(Kim과 Sim, 2017). 난백의 기포 형성은 부피와 부드러운 조직감을 갖도록 하므 로 이는 부피에도 영향을 미쳐 부피가 감소한 것으로 사료된 다. 설탕 첨가시 기포성은 감소하지만 난백의 점성이 증가하 면서 안정성이 높아진다(Lee 등, 2014). 환원당은 대조군이 $1.61 \%, 15 \%$ 첨가군이 $1.69 \%, 30 \%$ 첨가군이 $2.46 \%, 45 \%$ 첨 가군이 $2.79 \%$ 로 본문의 가용성 고형분 함량과 같이 증가하 는 결과를 보였다.

$\mathrm{pH}$ 는 대조군이 7.16 으로 실험군들 중 가장 높았으며, 흰 참깨 $15 \%$ 첨가군은 $6.87,30 \%$ 첨가군은 $6.84,45 \%$ 첨가군은 6.75 로 대조군보다 흰 참깨 첨가량이 증가할수록 첨가군이 감소하는 결과를 보였다. $\mathrm{pH}$ 는 제과시 첨가되는 부재료에 의 해 영향을 받는데, 참깨에는 산성 아미노산인 글루타민산 $(200 \mathrm{mg} / \mathrm{g})$ 과 아스파르트산 $(91 \mathrm{mg} / \mathrm{g})$ 이 전체 아미노산 조성 중에서 $18.2 \%$ 함유되어 있으며, 염기성 아미노산은 $12.5 \%$ 함유되어 있어 이러한 참깨의 아미노산 조성이 마카롱의 $\mathrm{pH}$ 에 영향을 준 것으로 사료된다(Park과 Kang, 2004). 또한, 산

Table 3. Soluble solid content, reducing sugar content, and pH of macaron added with white sesame powder

\begin{tabular}{|c|c|c|c|c|c|}
\hline & & \multicolumn{4}{|c|}{ White sesame powder (\%) } \\
\hline & & 0 & 15 & 30 & 45 \\
\hline \multicolumn{2}{|c|}{ Soluble solid content $\left({ }^{\circ}\right.$ Brix $)$} & $6.40 \pm 0.00^{1) \mathrm{d} 2)}$ & $6.50 \pm 0.00^{c}$ & $6.70 \pm 0.00^{\mathrm{b}}$ & $6.80 \pm 0.00^{\mathrm{a}}$ \\
\hline \multicolumn{2}{|c|}{ Reducing sugar content (\%) } & $1.61 \pm 0.02^{\mathrm{d}}$ & $1.69 \pm 0.01^{\mathrm{c}}$ & $2.46 \pm 0.02^{\mathrm{b}}$ & $2.79 \pm 0.07^{\mathrm{a}}$ \\
\hline \multicolumn{2}{|r|}{$\mathrm{pH}$} & $7.16 \pm 0.04^{\mathrm{a}}$ & $6.87 \pm 0.02^{\mathrm{b}}$ & $6.84 \pm 0.03^{\mathrm{b}}$ & $6.75 \pm 0.04^{\mathrm{c}}$ \\
\hline \multicolumn{2}{|r|}{ L* (lightness) } & $86.51 \pm 0.06^{\mathrm{a}}$ & $84.88 \pm 0.08^{\mathrm{b}}$ & $82.32 \pm 0.08^{\mathrm{c}}$ & $79.46 \pm 0.04^{\mathrm{d}}$ \\
\hline \multirow[t]{2}{*}{ Color value } & $\mathrm{a}^{*}$ (redness) & $2.55 \pm 0.03^{\mathrm{c}}$ & $2.59 \pm 0.01^{\mathrm{c}}$ & $3.09 \pm 0.04^{\mathrm{a}}$ & $2.99 \pm 0.03^{\mathrm{b}}$ \\
\hline & $\mathrm{b}^{*}$ (yellowness) & $16.43 \pm 0.04^{\mathrm{c}}$ & $15.57 \pm 0.02^{\mathrm{b}}$ & $17.75 \pm 0.24^{\mathrm{a}}$ & $17.73 \pm 0.18^{\mathrm{a}}$ \\
\hline
\end{tabular}

\footnotetext{
${ }^{1)}$ All values are mean $\pm \mathrm{SD}(\mathrm{n}=3)$.

${ }^{2)}$ Different letters $\left({ }^{\mathrm{a}-\mathrm{d}}\right)$ in the same row are significantly different by Duncan's multiple range test at $\mathrm{p}<0.05$.
} 
생성원소로 구성된 인지질과 같은 지방질이 많이 들어 있어 (Anilakumar 등, 2010) 참깨 첨가군에서 $\mathrm{pH}$ 가 감소한 것으 로 나타났다(Ryu 등, 2002). 율피 분말을 첨가한 쿠키(Joo와 Choi, 2012), 토마토 분말을 첨가한 머랭쿠키(Kim 등, 2016) 는 부재료에 의해 $\mathrm{pH}$ 가 감소하나, 아마씨 분말(Kim과 Chung, 2011), 흑임자 분말을 첨가한 쿠키(Lim과 Lee, 2015)는 증가 하였다. 제과 반죽의 $\mathrm{pH}$ 는 제품의 입자와 조직감, 부피에 영 향을 주며, 반죽이 산도가 강해질수록 기공과 부피가 작아지고 부드러워져(Joo와 Choi, 2012), 본 연구에서 부피의 감소에도 관련이 있는 것으로 사료된다. 이밖에 $\mathrm{pH}$ 는 완성된 제품의 향 과 표면의 색도에도 영향을 주는데(Kang과 Lee, 2007), 반죽 이 산성에 가까워질수록 색이 연해지고 알칼리성에 가까워질 수록 색이 어두워지며 강한 향과 소다맛이 난다고 하였다 (McWilliams, 1989). 본 논문에서는 모든 첨가군에서 중성에 가까운 $\mathrm{pH}$ 를 보여 크게 영향을 받진 않았지만 마카롱에 부재 료를 첨가하였을 때, 부재료에 의한 $\mathrm{pH}$ 조절은 중요한 작용 을 할 것으로 사료된다.

\section{색도}

흰 참깨를 첨가한 마카롱의 색도는 Table 3 과 같다. 명도 를 나타내는 $\mathrm{L} *$ 값은 대조군이 $86.51,15 \%$ 첨가군이 84.88 , $30 \%$ 첨가군이 $82.32,45 \%$ 첨가군이 79.46 으로 흰 참깨 비율 이 증가할수록 명도가 유의미하게 감소하였다 $(\mathrm{p}<0.05)$. 적색 도는 나타내는 $\mathrm{a}$ *값은 대조군이 $2.55,15 \%$ 첨가군이 2.59 , $30 \%$ 첨가군이 $3.09,45 \%$ 첨가군이 2.99 , 흰 참깨 첨가군에서 대조군보다 높은 적색도를 나타냈다. 황색도는 나타내는 $b^{*}$ 값은 대조군이 $16.43,15 \%$ 첨가군이 $15.57,30 \%$ 첨가군이 $17.75,45 \%$ 첨가군이 17.73 으로 $15 \%$ 첨가군에서는 대조군 보다 약간 낮은 수치를 보였으나, $30 \%$ 와 $45 \%$ 흰 참깨 첨가군 에서는 유의미하게 높은값을 보였다( $\mathrm{p}<0.05)$. 마카롱과 같은 쿠키의 색은 일정한 조건하에서 주로 당에 의한 영향이 크고
불안정한 당에 의한 카라멜 반응과 단백질의 아미노기와 환 원당의 알데하이드기에 의한 비효소적 갈변반응인 메일라드 반응에 의해 영향을 받는다(Bertram, 1953; Lee 등, 2007). 본 연구에서 흰 참깨 첨가량이 증가할수록 가용성 고형분 함 량과 환원당 함량이 모두 유의적으로 증가했고 $(\mathrm{p}<0.05)$ 흰 참깨 중의 단백질 함량도 $21.83 \%$ 로 높아, 이에 따라 굽는 과 정에서 메일라드 반응을 일으켜 색도에도 영향을 미친 것으 로 사료된다. 동시에 부재료의 첨가량에 의해서도 영향을 받 는데 흰 참깨분말의 색이 미색을 띄어 대조군보다 높은 $b^{*}$ 값 을 나타내는 것으로 보인다.

\section{기계적 조직감}

흰 참깨를 첨가한 마카롱의 기계적 조직감은 Table 4 와 같 다. 경도는 대조군이 $680.77 \mathrm{~g}$ 으로 가장 높았으며, $15 \%$ 첨가 군은 $569.27 \mathrm{~g}, 30 \%$ 첨가군은 $510.50 \mathrm{~g}, 45 \%$ 첨가군은 $443.26 \mathrm{~g}$ 으로 흰 참깨의 첨가량에 따른 감소 경향을 보였다. 쿠키의 경도는 첨가되는 부재료의 수분, 글루텐, 섬유소 함량 에 영향을 받는데(Joo 등, 2013), 흰 참깨를 부재료로 첨가시 흰 참깨 내 다량 함유되어 있는 지질에 의해 머랭의 불안정화 로 조직의 결합이 잘 이루어지지 않고 부피를 유지하는 힘이 감소하여 경도도 감소하는 것으로 사료된다(Lee 등, 2015). 반면, 쿠키의 경도가 높아지면 기호도가 감소되고 쉽게 부서 져 상품성이 하락한다(Moon과 Jang, 2011). 이는 땅콩분말 을 첨가한 마카롱과 유사한 결과였으며, 땅콩분말 $40-50 \%$ 첨가 마카롱군이 본 연구의 시료와 비슷한 수준의 경도를 보 였다(Park 등, 2020b). 탄력성과 응집성은 대조군과 흰 참깨 $15 \%$ 첨가군과 유의미한 차이는 없었으나( $\mathrm{p}>0.05)$, 흰 참깨 대체 비율이 높아질수록 감소하는 것으로 나타났다. 검성은 대조군이 113.62 로 가장 높았으며, $15 \%$ 첨가군이 $84.67,30 \%$ 첨가군이 $66.11,45 \%$ 첨가군이 31.21 로 흰 참깨 첨가군에서 는 대조군보다 검성이 낮은 것으로 나타났다. 씹힘성은 대조

Table 4. Texture analysis of macaron added with white sesame powder

\begin{tabular}{|c|c|c|c|c|}
\hline & \multicolumn{4}{|c|}{ White sesame powder $(\%)$} \\
\hline & 0 & 15 & 30 & 45 \\
\hline Hardness (g) & $680.77 \pm 15.67^{1) \mathrm{a} 2)}$ & $569.27 \pm 22.46^{\mathrm{b}}$ & $510.50 \pm 31.46^{\mathrm{c}}$ & $443.26 \pm 6.01^{\mathrm{d}}$ \\
\hline Springiness & $0.45 \pm 0.10^{\mathrm{a}}$ & $0.47 \pm 0.05^{\mathrm{a}}$ & $0.35 \pm 0.13^{\mathrm{ab}}$ & $0.26 \pm 0.07^{\mathrm{b}}$ \\
\hline Cohesiveness & $0.17 \pm 0.04^{\mathrm{a}}$ & $0.19 \pm 0.05^{\mathrm{a}}$ & $0.13 \pm 0.08^{\mathrm{ab}}$ & $0.06 \pm 0.00^{\mathrm{b}}$ \\
\hline Gumminess & $113.62 \pm 26.85^{\mathrm{a}}$ & $84.67 \pm 23.48^{\mathrm{a}}$ & $66.11 \pm 37.86^{\mathrm{ab}}$ & $31.21 \pm 3.40^{\mathrm{b}}$ \\
\hline Chewiness & $53.42 \pm 23.93^{\mathrm{a}}$ & $40.66 \pm 14.87^{\mathrm{ab}}$ & $26.19 \pm 24.70^{\mathrm{ab}}$ & $8.12 \pm 2.39^{\mathrm{b}}$ \\
\hline Resillience & $0.04 \pm 0.01^{\mathrm{a}}$ & $0.04 \pm 0.02^{\mathrm{a}}$ & $0.03 \pm 0.02^{\mathrm{ab}}$ & $0.01 \pm 0.00^{\mathrm{b}}$ \\
\hline
\end{tabular}

\footnotetext{
${ }^{1)}$ All values are mean $\pm \operatorname{SD}(\mathrm{n}=3)$.

${ }^{2)}$ Different letters $\left({ }^{\mathrm{a}-\mathrm{d}}\right)$ in the same row are significantly different by Duncan's multiple range test at $\mathrm{p}<0.05$.
} 
군이 $53.42,15 \%$ 첨가군이 $40.66,30 \%$ 첨가군이 $26.19,45 \%$ 첨가군이 8.12 로 경도와 같이 감소하는 것으로 보였다. 회복 력은 대조군이 $0.04,15 \%, 30 \%, 45 \%$ 첨가군이 각각 0.04 , $0.03,0.01$ 로 감소하는 경향을 보였다. 따라서 흰 참깨의 첨가 비율이 높아질수록 경도, 탄력성, 응집성, 검성, 씹힘성을 비 롯한 모든 조직감의 특성이 감소하여 조직이 촉촉하면서 부 드러워지는 반면, 쫀득한 정도는 감소하는 것으로 나타났다.

\section{총페놀성 화합물 함량}

흰 참깨를 첨가한 마카롱의 총페놀성 화합물 함량은 Fig. 1 과 같다. 대조군은 $1.10 \mathrm{mg} \mathrm{TAE} / \mathrm{g}$, 흰 참깨 $15 \%$ 첨가군은 $1.60 \mathrm{mg} \mathrm{TAE} / \mathrm{g}, 30 \%$ 첨가군은 $2.04 \mathrm{mg} \mathrm{TAE} / \mathrm{g}, 45 \%$ 첨가 군은 $3.23 \mathrm{mg} \mathrm{TAE} / \mathrm{g}$ 으로 흰 참깨 첨가량이 증가할수록 총페 놀성 화합물 함량이 증가했으며 시료들간 유의적 차이를 보였 다 $(\mathrm{p}<0.05)$. 페놀성 화합물은 식물계에 널리 있는 2 차 대사산 물의 주요 물질로 이들의 $\mathrm{OH}$ 기는 단백질 및 기타 거대 분자 들과 쉽게 결합하며, 미생물 세포와 작용하여 다양한 생리활 성을 가진다(Shahidi와 Naczk, 2004). 흰 참깨 중에는 세사 민, 세사몰린, 세사미놀, 세사몰과 같은 식물성 페놀성 화합 물인 리그난 물질이 함유되어 있으며 이들은 혈액이나 세포막 등에 있는 지방의 산화를 강력하게 억제하여 항산화 작용과 같은 생리활성을 보인다(Kamal-Eldin과 Appelqvist, 1994). 참깨는 다른 식물체와 비교했을 때도 특이적으로 우수한 리 그난 함량을 보이는데, 참깨는 $100 \mathrm{~g}$ 당 $834.57 \mathrm{mg}$ 의 리그난을 함유하고 있으며 그 다음으로는 아마씨가 $257.6 \mathrm{mg}$ 의 리그난 을 함유하고 있는 것으로 나타났다. 반면, 아몬드 $(0.10 \mathrm{mg})$ 는 매우 극미량의 리그난을 함유하고 있어 참깨와 큰 차이를 보 였다(Rodríguez-García, 2019). 이러한 리그난은 주로 배유부

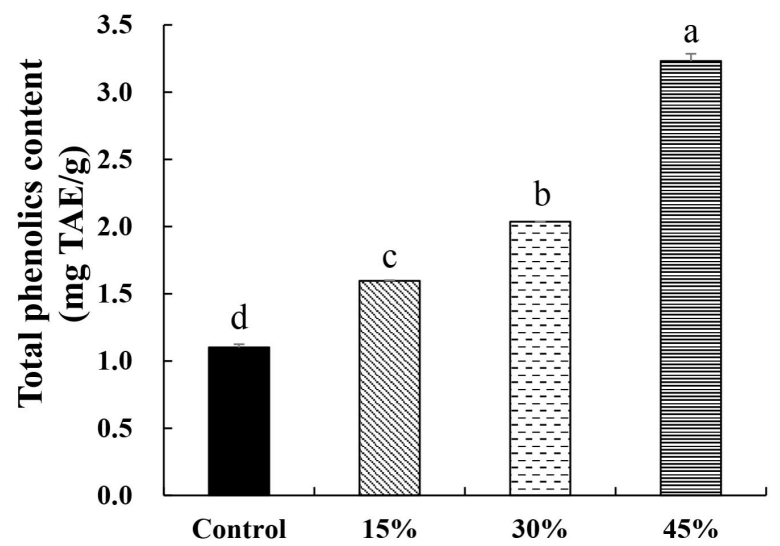

Fig. 1. Total phenolics content of macaron added with white sesame powder.

All values are mean \pm SD $(n=3)$.

Different letters $\left({ }^{a-d}\right)$ in the same row are significantly different by

Duncan's multiple range test at $\mathrm{p}<0.05$.
위에 존재하는데 검은깨의 종피율이 $15 \%$ 내외인데 반해, 흰 깨는 종피율이 $5.9 \%$ 로 낮아 세사민, 세사몰린 함량이 전체적 으로 흰깨에서 검은깨보다 2-4배 정도 높은 것으로 나타나 (Moazzami 등, 2007) 흰 참깨를 부재료로 사용함으로써 리 그난 물질 유래 생리활성 증진에 도움을 줄 것으로 사료된다.

\section{플라보노이드 함량}

흰 참깨를 첨가한 마카롱의 총 플라보노이드 함량은 Fig. 2 와 같다. 대조군은 $0.47 \mathrm{mg} \mathrm{NE} / \mathrm{g}, 15 \%$ 첨가군은 $0.48 \mathrm{mg}$ $\mathrm{NE} / \mathrm{g}, 30 \%$ 첨가군은 $0.54 \mathrm{mg} \mathrm{NE} / \mathrm{g}, 45 \%$ 첨가군은 $0.61 \mathrm{mg}$ $\mathrm{NE} / \mathrm{g}$ 으로 흰 참깨 첨가량에 따라 증가하는 경향을 보였다. 흰 참깨에는 리그난 화합물 이외에 토코페놀, 플라보노이드 등의 생리활성물질이 유리형 또는 배당체 형태로 존재한다. 참기름 제조 시 참깨의 부산물인 참깨박에서도 다양한 생리 활성 물질이 함유되어 있는데, 그 중에서 플라보노이드 또한 검출되어 기름을 짜고 난 후에도 거의 대부분 남아있는 것으 로 나타났다(Son과 Jang, 2013).

\section{DPPH radical 소거능}

흰 참깨를 첨가한 마카롱의 $\mathrm{DPPH}$ radical 소거능의 $\mathrm{IC}_{50}$ 값은 Fig. 3 과 같다. $\mathrm{IC}_{50}$ 값은 $\mathrm{DPPH}$ radical을 $50 \%$ 소거하 는데 필요한 농도로 대조군이 $1,593.20 \mathrm{mg} / \mathrm{mL}$, 흰 참깨 $15 \%$ 첨가군은 $1,284.82 \mathrm{mg} / \mathrm{mL}, 30 \%$ 첨가군은 $1,250.99 \mathrm{mg} / \mathrm{mL}$, $45 \%$ 첨가군은 $792.19 \mathrm{mg} / \mathrm{mL}$ 로 나타나 흰 참깨의 첨가량에 따라 유의적으로 낮아졌다 $(\mathrm{p}<0.05) . \mathrm{DPPH}$ radical 소거능은 안정적인 자유 라디칼 DPPH 시약과 항산화 성분이 반응하 여 환원되기 전 보라색 화합물에서 라디칼이 소거되어 노란 색으로 탈색되는 원리를 이용하는 측정방법이다(Foti 등,

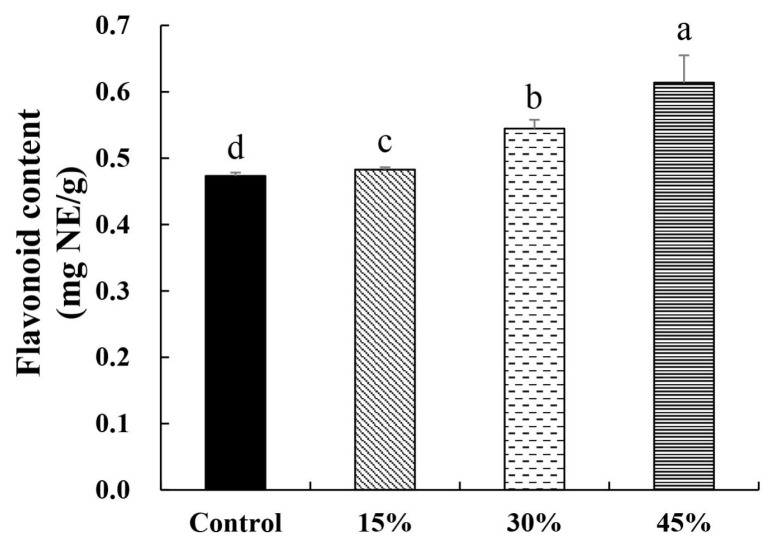

Fig. 2. Flavonoid content of macaron added with white sesame powder.

All values are mean \pm SD $(n=3)$.

Different letters $\left(^{\mathrm{a}-\mathrm{d}}\right)$ in the same row are significantly different by Duncan's multiple range test at $\mathrm{p}<0.05$. 


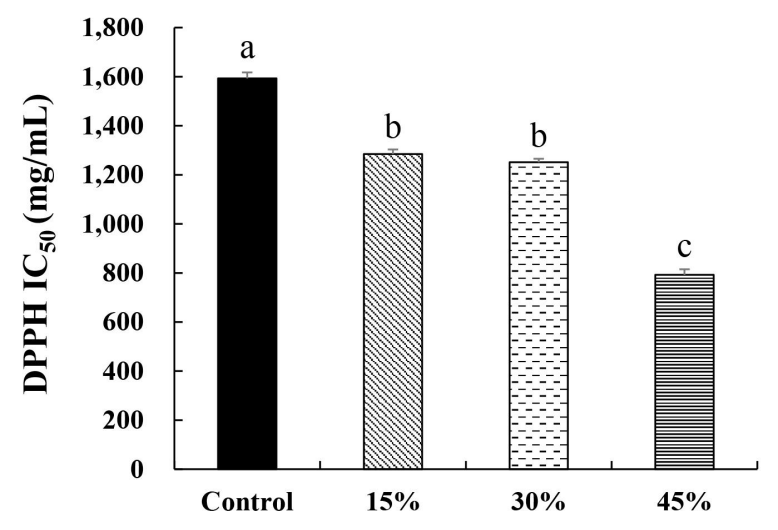

Fig. 3. $\mathrm{IC}_{50}$ value to scavenge DPPH radicals of macaron added with white sesame powder.

All values are mean \pm SD $(n=3)$.

Different letters $\left({ }^{a-c}\right)$ in the same row are significantly different by Duncan's multiple range test at $\mathrm{p}<0.05$.

2004). 환원력이 높은 페놀성 화합물이나 플라보노이드에 의 하여 높은 DPPH radical 소거능을 보이며, DPPH radical 소거 능이 높을수록 높은 항산화 활성을 나타낸다(Kang 등, 1996). 흰 참깨에서 이러한 항산화 성분으로 리그난 화합물 $(8,870$ $\mathrm{mg} / \mathrm{kg})$, 폴리페놀 $(548 \mathrm{mg} / \mathrm{kg})$, 토코페놀 $(700 \mathrm{mg} / \mathrm{kg})$ 이 발견 되었으며(Oh 등, 2018), 리그난류는 식품으로 섭취하면 가수 분해 효소인 $\beta$-glucosidase의 작용으로 당이 분리되어 세사미 놀과 피노레시놀의 형태로 혈액을 타고 각 조직으로 이동해 강한 항산화 효과 및 생체방어 효과을 내는 물질로 알려져 있다(Kang 등, 2000a). 따라서 앞선 결과와 같이 항산화력이 강한 리그난류 물질과 페놀성 화합물 및 토코페놀 성분의 증 가로 항산화 활성이 증대된 것으로 사료된다.

\section{SOD 유사활성}

흰 참깨를 첨가한 마카롱의 $\mathrm{SOD}$ 유사활성의 $\mathrm{EC}_{50}$ 값은 Fig. 4 와 같다. 대조군은 $2,055.55 \mathrm{mg} / \mathrm{mL}, 15 \%$ 첨가군은 $1,854.45 \mathrm{mg} / \mathrm{mL}, 30 \%$ 첨가군은 $1,242.49 \mathrm{mg} / \mathrm{mL}, 45 \%$ 첨가 군은 $1,042.52 \mathrm{mg} / \mathrm{mL}$ 로 흰 참깨 첨가량에 따라 유의적으로 $\mathrm{EC}_{50}$ 값이 감소하여 항산화능이 증가하는 것으로 나타났다 $(\mathrm{p}<0.05)$. 앞에서 언급한 바와 같이 참깨의 항산화 활성은 주 로 리그난 성분들에 의해 나타나며, 이외에 폴리페놀 물질과 토코페놀에 의해 SOD 유사활성을 나타내는 것으로 보인다. SOD 유사활성 결과와 총페놀성 화합물이 흰 참깨 첨가 비율 에 따라 거의 유사한 경향을 보이는 것으로 보아 흰 참깨 첨 가에 따른 영향이 있는 것으로 사료된다. 최근 건강과 웰빙에 대한 관심이 증가하면서 식물자원으로부터 산화적 스트레스 를 감소시킬 수 있는 천연 항산화제에 대한 연구가 활발하게 진행 중임에 따라(Kahkonen 등, 2001) 이러한 결과는 흰 참

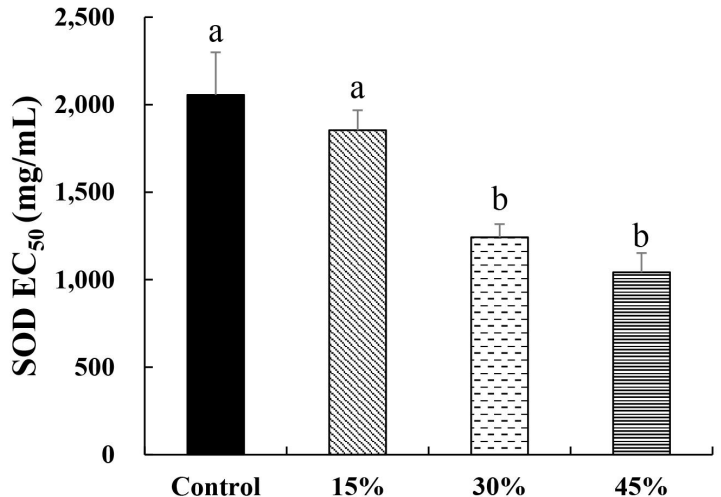

Fig. 4. $\mathrm{EC}_{50}$ value to SOD-like activity of macaron added with white sesame powder.

All values are mean \pm SD $(n=3)$.

Different letters $\left({ }^{\mathrm{a}-\mathrm{b}}\right)$ in the same row are significantly different by Duncan's multiple range test at $\mathrm{p}<0.05$.

깨를 첨가한 마카롱의 항산화성을 뒷받침할 수 있는 근거가 될 것으로 사료된다.

\section{관능평가}

흰 참깨를 첨가한 마카롱의 관능평가 결과는 Table 5 와 같 다. 색은 흰 참깨를 첨가할수록 점점 진하게 나타나 첨가량이 가장 많은 $45 \%$ 첨가군에서 3.8 점으로 나타나 대조군보다 높 은 수준을 보였다. 이는 색도(명도) 측정 결과와 같은 결과로 아몬드분말이 흰 참깨분말로 대체함으로써 색깔이 다소 어두 워지는 것으로 나타났다. 마카롱 외부의 매끄러운 정도는 대 조군이 5.4점으로 가장 높았으나, 흰 참깨의 첨가량에 따라 매끄러운 정도가 감소하는 것으로 나타났다. 마카롱은 구워 지는 동안 반죽의 머랭이 부풀게 되고 이때 수분이 머랭의 윗면의 막이 뚫고 나와 표면이 울퉁불퉁해지는 현상을 보이 며, 일반적인 잘 만든 마카롱의 형상은 납작하지 않고 표면이 매끈한 것으로 이는 대조군에서 가장 우수한 품질을 나타내 었다(Seo, 2019). 마카롱의 모양은 고소한 향은 흰 참깨의 향 의 첨가량과 함께 증가하여 $45 \%$ 첨가군이 보통보다 높은 수 준을 나타냈으며, 반면에 단향은 이와 반대로 흰 참깨 첨가량 에 따라 흰 참깨의 특유의 고소한 향으로 인해 상대적으로 더 약하게 느껴지는 것으로 보였다. 고소한 맛은 흰 참깨의 첨가 량에 따라 유의적으로 증가하여 가장 많이 첨가한 $45 \%$ 첨가 군에서 5.8 점으로 가장 높았다 $(\mathrm{p}<0.05)$. 단맛은 단향과 마찬 가지로 대조군에서 가장 높게 나타났으며, 흰 참깨가 첨가됨 에 따라 점차 감소하는 경향을 보였다. 촉촉한 정도는 대조군 이 2.8점으로 가장 낮았으며, 첨가군들의 경우에는 4.3-4.5점 으로 유의적인 차이는 나타나지 않았다 $(\mathrm{p}>0.05)$. 경도는 대 조군이 5.4 점, $15 \%, 30 \%, 45 \%$ 첨가군이 4.3점으로 동일하게 
Table 5. Sensory score of intensity test in macaron added with white sesame powder.

\begin{tabular}{|c|c|c|c|c|}
\hline & \multicolumn{4}{|c|}{ White sesame powder $(\%)$} \\
\hline & 0 & 15 & 30 & 45 \\
\hline Color & $1.0 \pm 0.0^{1)(2)}$ & $2.5 \pm 1.2^{\mathrm{b}}$ & $3.0 \pm 0.8^{\mathrm{ab}}$ & $3.8 \pm 1.2^{\mathrm{a}}$ \\
\hline Smooth & $5.4 \pm 2.2^{\mathrm{a}}$ & $4.3 \pm 1.2^{\mathrm{ab}}$ & $3.5 \pm 1.2^{\mathrm{bc}}$ & $3.5 \pm 1.2^{\mathrm{c}}$ \\
\hline Nutty flavor & $2.0 \pm 0.8^{\mathrm{c}}$ & $3.0 \pm 1.1^{\mathrm{c}}$ & $4.3 \pm 0.9^{\mathrm{b}}$ & $5.5 \pm 1.2^{\mathrm{a}}$ \\
\hline Sweet flavor & $6.0 \pm 1.1^{\mathrm{a}}$ & $4.3 \pm 0.5^{\mathrm{b}}$ & $3.8 \pm 1.6^{\mathrm{b}}$ & $3.3 \pm 1.2^{\mathrm{b}}$ \\
\hline Nutty taste & $2.4 \pm 0.7^{\mathrm{c}}$ & $2.8 \pm 0.9^{\mathrm{c}}$ & $4.5 \pm 0.9^{\mathrm{b}}$ & $5.8 \pm 0.9^{\mathrm{a}}$ \\
\hline Sweetness & $5.6 \pm 1.1^{\mathrm{a}}$ & $5.3 \pm 0.9^{\mathrm{ab}}$ & $4.5 \pm 0.9^{\mathrm{ab}}$ & $4.3 \pm 1.6^{\mathrm{b}}$ \\
\hline Moisture & $2.8 \pm 0.5^{\mathrm{b}}$ & $4.3 \pm 1.6^{\mathrm{a}}$ & $4.5 \pm 0.5^{\mathrm{a}}$ & $4.5 \pm 1.2^{\mathrm{a}}$ \\
\hline Hardness & $5.4 \pm 1.1^{\mathrm{NS} 3)}$ & $4.3 \pm 1.4$ & $4.3 \pm 0.5$ & $4.3 \pm 1.6$ \\
\hline Chewiness & $5.6 \pm 1.3^{\mathrm{a}}$ & $5.3 \pm 1.2^{\mathrm{a}}$ & $3.5 \pm 0.5^{\mathrm{b}}$ & $3.3 \pm 1.6^{\mathrm{b}}$ \\
\hline Dull & $2.0 \pm 0.8^{\mathrm{b}}$ & $3.0 \pm 1.7^{\mathrm{ab}}$ & $3.5 \pm 1.2^{\mathrm{a}}$ & $4.0 \pm 1.7^{\mathrm{a}}$ \\
\hline Overall acceptability & $4.0 \pm 0.9^{\mathrm{b}}$ & $5.5 \pm 1.6^{\mathrm{a}}$ & $5.5 \pm 0.5^{\mathrm{a}}$ & $4.3 \pm 0.9^{\mathrm{b}}$ \\
\hline
\end{tabular}

${ }^{1)}$ All values are mean $\pm \mathrm{SD}(\mathrm{n}=3)$.

${ }^{2)}$ Different letters $\left({ }^{\mathrm{a}-\mathrm{c}}\right)$ in the same row are significantly different by Duncan's multiple range test at $\mathrm{p}<0.05$.

${ }^{3)} \mathrm{NS}$, not significant.

나타나 기계적 조직감의 측정결과(Table 5)와 달리 흰 참깨 의 첨가량에 따라 시료들 간의 특성차이를 보이지 않는 것으 로 나타났다(p>0.05). 씹힘성은 대조군과 $15 \%$ 첨가군이 5.65.3점으로 비슷한 수준이였으며, $30 \%$ 첨가군부터 유의적으 로 감소하였다 $(\mathrm{p}<0.05)$. 마카롱의 텁텁한 정도는 대조군의 점수가 가장 낮았으며 흰 참깨의 첨가량에 따라 강도가 심해 지는 것으로 나타났다. 이는 흰 참깨분말이 입안의 수분을 흡 수하여 종실류 특유의 텁텁한 식감을 가지는 것으로 사료된 다. 마카롱의 전반적인 수용도는 $15 \%$ 첨가군과 $30 \%$ 첨가군 이 5.5점으로 가장 높게 나타났으며, 대조군 4.0 점, $45 \%$ 첨가 군 4.3점 순으로 나타났다.

관능평가 결과, 색과 매끄러운 정도 같은 외관과 고소한 향미가 흰 참깨가 첨가됨에 따라 대조군과 뚜렷한 차이를 보 였으며, 반면, 경도의 차이는 느끼지 못하는 것으로 나타났 다. 잘 만든 마카롱의 경우 내부를 잘라보면 속이 꽉 차 있으 며, 껍질과 안쪽의 바삭하면서도 촉촉한 식감, 단맛과 고소한 맛이 잘 어우러져 있는 것이라고 하였는데(Seo, 2019), 흰 참 깨가 첨가됨에 따라 이러한 특성을 보였다. 다만, $45 \%$ 첨가 군에서는 외관의 매끄러운 정도가 감소하고 텁텁한 정도가 증가함에 따라 전반적인 수용도도 다소 감소한 것으로 사료 되었다. 따라서, 외관과 맛, 향, 조직감을 모두 고려하였을 때, 희 참깨분말을 $15-30 \%$ 수준으로 첨가하는 것이 가장 우수한 품질을 가질 것으로 평가되었으며, 흰 참깨분말 첨가로 인한
외관과 텁텁한 식감 개선 등을 위한 연구가 향후 진행되어야 할 것으로 사료된다.

\section{요 약}

본 연구에서는 강력한 항산화 물질인 리그난 성분을 함유 하고 있으며, 여러 가지 생리활성을 지니고 있는 흰 참깨분말 을 이용한 마카롱을 개발하고자 하였다. 이를 위하여 흰 참깨 분말을 아몬드분말의 $15 \%, 30 \%, 45 \%$ 씩 각각 다른 비율로 첨가하여 마카롱을 제조한 후, 이화학적 품질 특성과 항산화 성 실험을 진행하였다. 수분함량은 흰 참깨분말 첨가량이 증 가함에 따라 미세한 차이로 증가하여 $45 \%$ 첨가군에서 가장 높게 나타났다. 마카롱의 무게는 수분함량과 같은 결과로 대 조군에 비해 흰 참깨 첨가군에서 높은 값을 나타낸 반면, 부 피는 흰 참깨 첨가군에서 더 낮게 나타나 반대의 양상을 보였 다. 가용성 고형분 함량과 환원당 함량은 흰 참깨 첨가량에 따라 유의적으로 증가하는 경향을 나타냈으며, $\mathrm{pH}$ 는 흰 참깨 의 첨가량에 따라 유의적으로 감소하는 결과를 보였다. 마카 롱의 색도는 명도를 나타내는 $\mathrm{L}^{*}$ 값은 대조군이 가장 높았으 며 흰 참깨의 첨가량에 따라 감소하여 어두워졌다. 각각 적색 도와 황색도를 나타내는 $\mathrm{a}^{*}$ 값과 $\mathrm{b}$ *값은 대조군보다 첨가군 에서 더 높게 나타났다. 마카롱의 조직감 측정결과는 흰 참깨 첨가량이 높아질수록 경도, 검성, 씹힘성이 감소하는 경향을 
보였다. 총페놀성 화합물과 플라보노이드 함량은 흰 참깨를 첨가량에 따라 증가하는 경향을 보였으며, DPPH radical 소 거능과 $\mathrm{SOD}$ 유사활성 모두 증가하여 흰 참깨의 페놀성 물 질, 리그난 성분과 토코페롤들이 항산화능에 영향을 미치는 것으로 사료된다. 관능검사에서는 $15 \%$ 와 $30 \%$ 첨가군의 전 반적인 수용도가 높게 나와 관능적인 측면에서는 흰 참깨분 말을 아몬드분말의 $15-30 \%$ 수준으로 첨가하는 것이 적절할 것으로 판단된다. 이를 결과로 흰 참깨분말 첨가군에서 항산 화능과 전반적인 수용도가 높아져 생리활성 효과와 기호도 증진의 결과를 입증하였으며, 앞으로 흰 참깨를 첨가한 마카 롱 개발의 가능성과 기초자료를 제시할 수 있을 것으로 기대 된다.

\section{Conflict of interests}

The authors declare no potential conflict of interest.

\section{ORCID}

$\begin{array}{ll}\text { Su Jin Kim } & \text { https://orcid.org/0000-0002-5151-2247 } \\ \text { Mee Ree Kim } & \text { https://orcid.org/0000-0003-3813-1447 }\end{array}$

\section{References}

AACC. Approved Methods of the AACC. 10th ed, AACC, St Paul, MN, USA (2000)

Anilakumar KR, Pal A, Khanum F, Bawa AS. Nutritional, medicinal and industrial uses of sesame (Sesamum indicum L.) seeds-an overview. Agric Conspec Sci, 75, 159-168 (2010)

Bertram GL. Studies on crust color. I. The importance of browning reaction in determining the crust color of bread. Cereal Chem, 30, 127-139 (1953)

Chae YC. The role of bakery and eggs. Culi Sci Hos Res, 3, 367-383 (1997)

Cornwell T, Cohick W, Raskin I. Dietary phytoestrogens and health. Phytochemistry, 65, 995-1016 (2004)

Dupasquier CMC, Weber AM, Ander BP, Rampersad PP, Steigerwald S, Wigle JT, Mitchell RW, Kroeger EA, Gilchrist JSC, Moghadasian MM, Lukas A, Pierce GN. Effects of dietary flaxseed on vascular contractile function and atherosclerosis during prolonged hypercholesterolemia in rabbits. Am J Physiol Heart Circ Physiol, 291, H2987-H2996 (2006)

Foti MC, Daquino C, Geraci C. Electron-transfer reaction of cinnamic acids and their methyl esters with the DPPH • radical in alcoholic solutions. J Org Chem, 69, 23092314 (2004)

Fukuda Y, Nagata M, Osawa T, Namiki M. Contribution of lignan analogues to antioxidative activity of refined unroasted sesame seed oil. J Am Oil Chem Soc, 63, 1027-1031 (1986)

Hong SJ, Yoon HH. Quality characteristics of macarons made with pumpkin seed powder. J East Asian Soc Diet Life, 30, 59-65 (2020)

Hosseinian FS, Muir AD, Westcott ND, Krol ES. Antioxidant capacity of flaxseed lignans in two model systems. J Am Oil Chem Soc, 83, 835-840 (2006)

Hou RCW, Huang HM, Tzen JTC, Jeng KC. Protective effects of sesamin and sesamolin on hypoxic neuronal and PC12 cells. J Neurosci Res, 74, 123-133 (2003)

Hwang MH. Physicochemical and sensory characteristics of macaron replaced with grain powder by almond powder. $\mathrm{Ph}$ D Thesis, Chungnam National University, Korea (2020)

Ide T, Ashakumary L, Takahashi Y, Kushiro M, Fukuda N, Sugano M. Sesamin, a sesame lignan, decreases fatty acid synthesis in rat liver accompanying the downregulation of sterol regulatory element binding protein-1. Biochim Biophys Acta Mol Cell Biol Lipids, 1534, 1-13 (2001)

Joo SY, Choi HY. Antioxidant activity and quality characteristics of cookies with chestnut inner shell. Korean J Food Nutr, 25, 224-232 (2012)

Joo SY, Kim OS, Jeon HK, Choi HY. Antioxidant activity and quality characteristics of cookies prepared with acorn (Quercus species) powder. Korean J Food Cook Sci, 29, 177-184 (2013)

Jung KJ, Lee SJ. Quality characteristics of rice cookies prepared with sea mustard (Undaria pinnatifida Suringer) powder. J Korean Soc Food Sci Nutr, 40, 1453-1459 (2011)

Kahkonen MP, Hopia AI, Heinonen M. Berry phenolics and their antioxidant activity. J Agric Food Chem, 49, 40764082 (2001)

Kamal-Eldin A, Appelqvist LA. Variation in fatty acid composition of the different acyl lipids in seed oils from four Sesamum species. J Am Oil Chem Soc, 71, 135-139 (1994)

Kang MH, Kawai Y, Naito M, Osawa T. Dietary defatted 
sesame flour decreases susceptibility to oxidative stress in hypercholesterolemic rabbits. J Nutr, 129, 1885-1890 (1999)

Kang MH, Naito M, Sakai K, Uchida K, Osawa T. Mode of action of sesame lignans in protecting lowdensity lipoprotein against oxidative damage in vitro. Life Sci, 66, 161-171 (2000a)

Kang MH, Ryu SN, Bang JK, Kang CH, Kim DH, Lee BH. Physicochemical properties of introduced and domestic sesame seeds. J Korean Soc Food Sci Nutr, 29, 188-192 (2000b)

Kang NE, Lee IS. Quality characteristics of the sugar cookies with varied levels of resistant starch. Korean J Food Culture, 22, 468-474 (2007)

Kang YH, Park YK, Lee GD. The nitrite scavenging and electron donating ability of phenolic compounds. Korean J Food Sci Tehonol, 28, 232-239 (1996)

Kanu PJ. Biochemical analysis of black and white sesame seeds from China. Am J Biochem Mol Biol, 1, 145-157 (2011)

Kim KH, Kim YS, Hong MS, Yook HS. Quality characteristics of meringue cookies added with tomato powder. J Korean Soc Food Sci Nutr, 45, 366-371 (2016)

Kim KJ. Quality characteristics and antioxidant activities of macaron with cabbage powder. Food Eng Prog, 21, 367-374 (2017)

Kim M, Sim KH. Quality characteristics and antioxidative activities of macaron with the addition of egg white powder. Korean J Food Nutr, 30, 269-281 (2017)

Kim SY, Chung HJ. Quality characteristics of cookies made with flaxseed powder. Food Eng Prog, 15, 235-242 (2011)

Koo SH. Parisien Macaron. Pampas, Seoul, Korea, p 49-79 (2018)

Kumamoto H, Matsubara Y, Iizuka Y, Okamoto K, Yokoi K. Structure and hypotensive effect of flavonoid glycosides in Kinkan (Fortunella japonica) peelings. Agric Biol Chem, 49, 2613-2618 (1985)

Lee JH, Kim MR, Min HS, Lee YE, Song ES, Kwon SJ, Kim MJ, Song HN. The Food \& Principle of Cookery-A Scientific Approach. Kyomunsa, Paju, Korea, p 298-299 (2014)

Lee MW, Choi SY, Yoo KM, Lim SY, Jung WS, Hwang IK. Development of value-added macarone with Perilla frutescens powders and their physiological characteristics. Korean J Food Nutr, 28, 66-72 (2015)

Lee SJ, Shin JH, Choi DJ, Kwen OC. Quality characteristics of cookies prepares with fresh and steamed garlic powders. J Korean Soc Food Sci Nutr, 36, 1048-1054 (2007)

Lim JA, Lee JH. Quality and antioxidant properties of cookies supplemented with black sesame powder. J Korean Soc Food Sci Nutr, 44, 1058-1063 (2015)

McWilliams M. Foods Experimental Perspectives. MacMillian Publishing Company, New York, NY, USA, p 358-359 (1989)

Miller RA, Hoseney RC, Morris CF. Effect of formula water content on the spread of sugar-snap cookies. Cereal Chem, 74, 669-671 (1997)

Miura T, Yuan L, Sun B, Fujii H, Yoshida M, Wakame K, Kosuna $\mathrm{K}$. Isoflavone aglycone produced by culture of soybean extracts with Basidiomycetes and its antiangiogenic activity. Biosci Biotechnol Biochem, 66, 2626-2631 (2002)

Moazzami AA, Haese SL, Kamal-Eldin A. Lignan contents in sesame seeds and products. Eur J Lipid Sci Technol, 109, 1022-1027 (2007)

Moon YJ, Jang SA. Quality characteristics of cookies containing powder of extracts from Angelica gigas Nakai. Korean J Food Nutr, 24, 173-179 (2011)

Namiki M. Nutraceutical functions of sesame: A review. Crit Rev Food Sci Nutr, 47, 651-673 (2007)

Namiki M. The chemistry and physiological functions of sesame. Food Rev Int, 11, 281-329 (1995)

Oh B, Shin M, Choe E. Effect of binder composition on the stability of lipid oxidation and antioxidants of nutsesame yeotgangjeong (Korean traditional candy bar). Korean J Food Sci Technol, 50, 280-285 (2018)

Orruno E, Morgan MRA. Purification and characterisation of the 7S globulin storage protein from sesame (Sesamum indicum L.). Food Chem, 100, 926-934 (2007)

Park SJ, Kang MH. Functional properties of sesame seed. Food Industry and Nutrition, 9, 31-40 (2004)

Park YM, Kim DH, Kim SJ, Kim MR. Effect of storage conditions on the storage characteristics of macarons. Korean J Food Preserv, 27, 291-298 (2020a)

Park YM, Kim SJ, Kim DH, Kim MR. Physicochemical properties of macaron supplemented with peanut (Arachis 
hypogaea L.) powder. J Korean Soc Food Sci Nutr, 49, 377-384 (2020b)

Pyler EJ. Physical and chemical test method. In: Baking Science and Technology. Soland Pub Co., Kansas, USA, p 891 (1979)

Rodriguez-Garcia C, Sanchez-Quesada C, Toledo E, Delgado-

Rodriguez M, Gaforio JJ. Naturally lignan-rich foods: A dietary tool for health promotion?. Molecules, 24, 917 (2019)

Ryu SN, Kim KS, Lee EJ. Current status and prospects of quality evaluation in sesame. Korean J Crop Sci, 47, 140-149 (2002)

Seo KY. Brechel Macaron One Book. Booksoyu, Seoul, Korea, p 10-50 (2019)

Shahidi F, Naczk M. Phenolic in Food and Nutraceuticals. CRC Press, Boca Raton, FL, USA, p 403-442 (2004)

Son JY, Jang SH. Physiological activities of enzyme hydrolysates in ethanol extracts from sesame, black sesame and perilla cake. Korean J Food Cookery Sci, 29, 407-416 (2013) 